\title{
CONCEPTUALISATION OF ACADEMIC STAFF'S DIDACTIC PRACTICES IN THE CONTEXT OF PROFESSIONALISATION
}

\author{
Birutė Jatkauskienė \\ Elvyra Acienè \\ Klaipeda University, Lithuania
}

\begin{abstract}
The article presents a theoretical discourse of academic staff's didactic practices with a particular emphasis on importance of conceptualisation of their didactic practices in the professionalisation context. The authors analyse the essence of didactic practice conceptualisation studies and their contribution to the professionalisation process, disclose the interrelations of conceptualisation of didactic practices and lecturers' professional behaviour, their role-playing and models of didactic practices, that are oriented to the study process organisation, planning programmes, modules and classes, a search of information transmittal forms, the use of advanced teaching methods, as well as student counselling and communication. On the basis of the didactic practice conceptualisation studies, the authors argue that the analysis of conceptualisation of lecturers' didactic practices and their professional behaviour (performance models, roles) can be helpful in adding missing elements to the professionalisation of academic staff and suggest strategies for professional development.
\end{abstract}

Keywords: conceptualisation of didactic practices, model of didactic practices, a lecturer's professional behaviour, roles, professionalization.

\section{Introduction}

Individual professionalisation - becoming a professional - is a long and complicated process. High dedication, time, motivation, and persistence are demanded when accumulating specific scientific knowledge essential to run professional activities, when acquiring experience, applying theoretical knowledge in practice, building and renewing a professional identity, and improving skills. On the other hand, a person wanting to become a lecturer should be able to conceptualise in a proper way, that is, realize him/herself and be able to explain what his/her professional activities mean, what knowledge and skills are needed for running the said activities, to construct and direct it.

Lecturers who are ready (and/or have been trained) to become researchers of their field of science often lack didactic knowledge, skills, experience 
required to run their pedagogical (as we say) activities. In other words, university lecturers rarely acquire knowledge or skills in higher education didactics before starting their professional activities, not to mention experience, even though previous studies, conducted in a number of countries, show that a lecturer's pedagogical activities, based on didactic excellence in higher education, is one of the main determinants of students' learning outcomes and the quality of studies (Langevin, 2007). We may supplement this argument by the fact that academic staff focuses essentially on pedagogical activities, by giving efforts, time and preparation for it, since they believe it still remains one of the priority areas today (Jatkauskienè et al., 2013). Teaching activities are diverse and encompass drawing up and execution of curricula, modules, conducting lectures and classes, arrangement of tutorials, practice, supervision of students' graduation works, practice, student counselling, assessment, and so on. N. Šedžiuvienė (2005) points out that lecturers' pedagogical activities consist of two elements - visible and "implicit", invisible. An invisible element means the process of designing of learning and study processes, planning of curricula, modules, and classes, while visible activities - didactics - involve information sharing, conducting classes and practical training, student counselling, communication, etc. It sounds paradoxically that academic staff is quite often found to be inadequately trained for such visible didactic practices. Research conducted in Klaipeda University (Jatkauskienè et al., 2013), has demonstrated that lecturers lack didactic knowledge and skills in higher education; some of the academic staff inadequately perceive their functions, while a conceptualisation of practices manifests itself as certain activity patterns, reference points, helping lecturers to realize, explain, focus, and construct their didactic practices, professional behaviour, and development (Neyts et al., 2006). Accordingly, it casts doubt on academic staff's professionalism and development of it.

Didactic education is not mandatory for academic staff of Lithuanian universities. In other words, lecturers need no prior didactic experience in higher education to be employed at a university. Didactic skills in higher education are usually developed as late as during certain postgraduate studies. Not infrequently, a university professor never takes any professional development programme in higher education didactics throughout his/her careers (Jatkauskiene et al., 2013). When talking with peers, one can often hear that they have learned to teach after adopting, in their opinion, a best teacher's performance model and professional behaviour. Then, the question arises as to why university focuses in didactics so little. The more especially as Comenius, who published his Didactica magna (The Great Didactic) in 1657, stated a clear and ambitious goal in the subtitle - "The whole Art of Teaching all Things to all Men." Maybe, didactics is "kicked out" of the campus just because it is not as "respectable" discipline as philosophy, medicine, the arts, or languages, etc.? 
Maybe, a university values science only, but not studies or a student who just occasionally reveals systematic scientific truths? Nonetheless, sooner or later, a university when faced with a new generation of students, their needs and demands for academic staff's professionalism, will be forced to consider how to implement a higher school didactics in a lecturers' professionalisation process or a strategy for university activities.

Once higher education has grown into a mass phenomenon, students are becoming an increasingly heterogeneous group of learners in terms of knowledge, experience, skills, age and other aspects. Therefore, traditional didactic methods, forms and techniques of teaching practices, that have established since medieval ages (lectio et disputatio), come under criticism of students, social peers, employers as inadequately meeting the learning needs of today's generation of students as well as a mission of a university.

In pursuance of positive changes in lecturers' pedagogical practice, it is necessary to go into (and, sometimes, to change) their personal perception of didactic practice, its explanation and construction (conceptualisation). In other words, a lecturers' attitude toward a learning student, their professional behaviour, performance models, their and a student's roles, their relationships, and interaction require a more comprehensive analysis for promoting the professionalisation process on a basis thereof.

It is quite difficult to give an unambiguous answer to the question of what determines professionalism of academic staff (A number of publications? Degree? The title of pedagogue? Taking part in conferences, projects? Positive student feedbacks?) While answering this question, other questions may arise: what is lecturers' readiness for academic activities? How do lecturers perceive, are they able to explain, to conceptualise their didactic practices? What are the organisational structure, functions, typical performance situations that occur to the majority of university academic staff? What are didactic skills in higher education, didactic practice models, behaviour that are necessary to control such performance situations? In other words, a consideration should be given to how to become a professional in teaching (learning through experience, i.e., becoming a skilled blacksmith by forging iron all the day long... or otherwise?)

The goal of this article is to review previous studies related to the conceptualisation of academic staff's didactic practices and to disclose the importance of it in the context of professionalisation.

The issues of conceptualisation of academic staff's didactic practices and professionalisation still have a status of a "poor cousin" within the Lithuanian (and not only) study field. Therefore, the article attempts to answer the following problematic issues:

1. What is the essence of studies in conceptualisation of didactic practices and their contribution to professionalisation? 
2. What are the interrelations of conceptualisation of didactic practices and professional behaviour, role-playing, and models of didactic practices?

3. Is consideration of diverse conceptualisation of lecturers' didactic practices, their professional behaviour, and analysis thereof be able to provide necessary elements to professionalisation, to point out appropriate professional development ways or means?

The article writing has involved review of scientific literature and metaanalysis. References in Lithuanian, English, and French have been selected for the analysis on the basis of a key parameter - appropriation of a reference source for the scientific publication which analyses the conceptualisation of academic staff's didactic practices and their professionalisation.

First, we review scientific publications related to conceptualisation of student learning activities and only then - publications related to conceptualisation of lecturers' didactic activities in the historical perspective of this research area. The publications have been selected and analysed with regard to the above key problematic issues and with an emphasis on the idea of didactic practice conceptualisation, concepts of didactic practices, interrelations of conceptualisation and operational changes, professionalization, etc.

This article is based on the constructivist educational concept, according to which any social reality refers directly to performance and interactions of social actors, their symbolic or tangible practice (Legendre, 2004). Social actors, however, create, mobilise, and resort to various representations, different constructs of mentality and experience based on which they interpret social reality and influence it, since human thinking and insight always need visualily (Jaspers, 1998, p 5). It should be noted that the social actors' constructs do not just exist in a space: they have a situational, local nature. In other words, they are interfering with a specific, social context, which involves other social actors, too, and where a variety of human activity products (e.g., goods, tools, organizations, laws, etc.) are produced. This means that social actors are not able to explain, share available representations, or to negotiate, as their social reality concepts are comprised in an enclosed, purified, unchangeable, and subjective space. That is, social reality depends both on a particular actor and interaction partners.

Such methodological provisions presume that university lecturers, as well as other social actors describe and interpret a significant part of their performance objectives to themselves and others with regard to emerging didactic and learning process concepts of their own and their students. To summarise, lecturers' performance objectives can be argued to be not strongly predetermined by outside environment, they rather depend on corresponding interpretative and constructive activities, given the performance objectives and 
the means selected for the attainment of the said objectives by the lecturers. Together, it should be noted that interpretations and constructs of the actual teaching activities are integrated into the organisational context of a university, communication with peers and students. Consideration, therefore, must be given to other actors' opinions, approaches, attitudes, communication and operational rules, organisational norms, values, and so on. All this quite often becomes a means of professional learning for lecturers. Based on this approach, we can define educational concepts as performance patterns, reference points which enable lecturers to understand, develop, focus, and explain their didactic practices at the beginning of their pedagogical activities. This is a global vision of teaching staff's didactic practices, obliging them to acquire excellence not only in their own discipline, but in specific subjects (for example, knowledge of didactics and andragogy in higher education, areas of teaching activities, organisational aspects of university, and so on), too. Solely this knowledge and excellence enable to realize, build, and run one's own professional activities, build relationships with students, and develop didactic lecturer-to-student learning activities in an efficient way.

\section{Essence of studies in conceptualisation of didactic practices and contribution to professionalisation}

The process of becoming a professional for academic staff, as well as other social actors, i.e., professionalisation, is a lengthy process, taking more than a day or a week. This process involves different ways and means. One of them is a conceptualisation of didactic practices (a visible part of a lecturer's pedagogical activities).

Conceptualisation of didactic practices refers to a lecturer's experience, performance representations (Jatkauskienè et al., 2014). And this is really important for professional development of lecturers, for emergence and growth of a "hard core" of their didactic skills. An importance and benefits of the conceptualisation of didactic practices for professional development have stimulated scientific studies in this area.

Some of the earliest studies (Romainville, 1998) as of the late 20th century were designed to examine a conceptualisation of students' learning activities, interaction between students and lecturers, through a variety of didactic and learning strategies. These studies revealed what was called a "hard core" structuring, including meta-cognition, of student behaviour (Romainville, 1996, p. 64). At the same period $\left(8^{\text {th }}-10^{\text {th }}\right.$ decade of the 20 th century), there were studies in conceptualisation of teachers' didactic practices simultaneously launched. The initiator of many of them was the Anglo-Saxon higher school and its representatives, who were later joined by scholars from other countries. It 
should be noted that a number of studies (Fox, 1983; Dunkin, 1990) were specially designed to conceptualise a performance of academics "just embarking on a teaching career". D. Fox proposed and justified a conceptual model of teaching, aimed to look deeper into the teaching activities of a lecturer and learning activities of students. The researcher kept giving one and the same question to teachers for several years running, "What do you mean by teaching?" On the basis on the responses received, D. Fox has developed a conceptual model and identified several theories of teaching (Fox, 1983, pp. 157-158):

- $\quad$ transfer theory that treats knowledge as a commodity to be transferred from one vessel to another;

- shaping theory that treats teaching as a process of shaping or moulding students' behaviour, knowledge, and skills to a predetermined pattern;

- travelling theory, which treats a subject of teaching as a terrain to be explored with hills to be climbed for better viewpoints with the teacher as the travelling companion or expert guide;

- growing theory, which focuses more on the intellectual and emotional development of a learner.

The above theories can be argued to match and reflect not only conceptualisation of academic staff's didactic practices, but students' attitude toward learning/studies, too. All the listed theories of teaching can be figuratively divided into two groups: simple theories (e.g., transfer and shaping) and developed, complex (e.g., travelling and growing) (Fox, 1983, p. 158). However, it should be noted that regardless of a theory chosen by a lecturer to base his/her activities upon so as to improve the didactic process, each of them reflects the lecturer's strategy and correlates with his/her position, attitude toward a student, his/her learning, curricula, subject content, etc.

M. J. Dunkin (1990), in the study of professional integration of university teachers, interviewed 55 new lecturers at an Australian university. The goal - to reveal early experiences in the institution and attitudes regarding teaching and student evaluations. The study data were used to analyse professional integration of the newly employed lecturers, whose expectations with respect to professional integration and their experience were used as a key criterion for initial data analysis. Effects (and results) of the professional integration under the concept of didactic practices became the second criterion of data analysis. M. J. Dunkin (1990, p. 127) identified four elements for description and analysis of didactic concepts: structure of learning, motivation to learning, encouragement to act and pursue learning autonomy (independence from a 
lecturer or group members) and building the relationships to facilitate the learning process.

During the study, analysis and identification of didactic concepts, expressed at early career, has revealed that lecturers often apply not all of the above concepts at the beginning of their careers. Therefore, their didactic practices are to be improved, because conceptualisation of the practices is inadequate and is quite narrow.

Subsequent qualitative studies in the conceptualisation of lecturers' didactic practices have revealed similar trends (Dall'Alba, 1991). During the studies, there were identified seven concepts of lecturers' didactic practices: from didactics for the delivery and conveying of information to didactic practices, implying conceptual changes in learning activities. Different concepts of didactic practice have been studied and described by a number of authors: P. Ramsden (2003), who justified in his study three different personal concepts of teaching; K. Samuelowicz et al. (1992), who identified five qualitatively different concepts of lecturers' didactic concepts - from conveying of information to conceptual changes in learning/studies and support/assistance for a learner.

A brief review of lecturers' didactic concepts and primary studies allow assuming that the conceptualisation of teaching is treated differently by various authors, yet, let us identify the following several general trends:

- lecturers who perceive their didactic practices as a knowledge transfer process vs. lecturers who perceive their didactic practices as support/assistance to students;

- conceptualisation of didactic practices of lecturers, even those teaching the same course, can be very different;

- different hierarchical elements can be identified in the conceptualisation of lecturers' didactic practices;

- conceptualisation of lecturers' didactic practices correlates with the selected didactic strategy and didactic intentions.

Therefore, other authors (Trigwell et al., 1994) focused their studies on the following elements: a concept of didactic practices, strategy and intentions of a lecturer.

Research findings (e.g., Romainville, 1996, p. 67) highlight the following intentions of lecturers: "lecturers' didactic strategies oriented to him/herself and to the intention of conveying knowledge to students." In this case, a lecturer focuses all his/her attention to the mastery of a content of a subject taught, conveying of a content, etc. Hence, a student's role is rather passive. In contrast, the other teaching strategy is focused on a student and a lecturer's intention to support the student's conceptual changes. Learning in this case is understood as 
a conceptual change. A student, willing to learn something, must not only construct knowledge or a system of it, but also to confront existing concepts in a particular manner with a view of their qualitative changes. A lecturer's intentions with respect to a learner can be, respectively, of restrictive or motivational nature.

The top position in hierarchy of the conceptualisation of didactic practices belongs to the element known as a lecturer's activities, focused on conceptual changes in learning/studies, and the lowest - to didactic practices as conveying of knowledge, information (Dall'Alba, 1991; Ramsden 2003; Samuelovicz etc., 1992; Trigwell, 1995).

Another and obviously most important finding of the above studies in terms of professionalisation is that in pursuance of positive changes in lecturers' didactic practices, it is necessary to change their personal perception of the practices, i.e., their attitude towards a learner, their and a student's roles, their relationships, interactions. It was, therefore, suggested to name the concepts of didactic practices as lecturers' personal concepts of didactic practices, given the nature of their teaching activities. Some authors (Samuelowicz et al., 1992) regard concepts of didactic practices as theories of teaching, because this is direct didactic experiences tried and applied by a lecturer (Samuelowicz et al., 1992, p. 97). Approaches of D. Fox (1983) and M. J. Dunkin (1990) match the one of the above author (Samuelowicz et al., 1992). This explains why the efforts to improve lecturers' didactic work process, given that a lecturer takes actions during classes only, and regardless of the conceptualisation of his/her activities, are worth to develop the methodology and strategy of the didactic practices, but not always, as being focused on facilitation or support for a student learning. Improvement of didactic practices should start with changes in thinking, didactic strategies, reflection of methodology applied. Those lecturers, who disregard personal mindset changes, will disregard a didactic strategy to be applied in their activities, as well. Together, such lecturers are not concerned about helping students in pursuing conceptual changes (Trowler et al., 2011).

\section{Conceptualisation of activities. Interrelations of lecturers' professional behaviour, roles, and models of didactic practices}

Studies in higher school didactics, conceptualisation of academic staff's didactic practices (Kember, 1997; Saussez, 1998; Kane et al., 2002; Loïola 2001; et al.) became particularly intensive in the last decade of 20th century and in the beginning of the 21 st century. This intensiveness can be explained by the fact that scientific studies were aimed to validate the hypothesis: teachers' behaviour during classes largely depends on the conceptualisation of their didactic practices (Donnay et al., 1996; Ramsden, 1992; Trigwell, 1995 et al.). 
This hypothesis was originally applied only to the analysis of performance of experienced teaching staff (Kember, 1997; Kane et al., 2002; Pratt, 1992; Saussez, 1998). The studies revealed the following trend: the majority of lecturers are poorly aware of available models for running didactic practices, the diversity of behaviours, roles and their opportunities. However, to become a professional, one needs to understand, to be able to explain his/her professional behaviour, i.e. performance methods, roles, didactic models, etc., because future insights mean today's perception, understanding, a choice of adequate behaviour of a reflecting practitioner in various areas of professional activities (Schön, 1994, p. 53).

A model of didactic practices is defined as a whole of interlinking didactic actions resting upon representations of a human being (an individual), society's didactic practices and learning (Legendre, 2005, p. 896). Models of didactic practices are quite different: some are transmissible, others are behavioural, constructivist or socio-constructivist, meta-cognitive, etc. It is no secret that the lecturers with no didactic framework in higher education may not be aware of the existence of didactic models, their variety and applicability.

However, knowledge of models of didactic practices is essential not only to conceptualise lecturers' didactic practices, to analyse their professional behaviour, to assess their professionalism, etc. The excellence in the above is essential for many other reasons, for example:

- not all people are able to learn the same things by the same means or methods (Clanet, 2004);

- a teacher of literacy must apply various methods and means in his/her didactic practices, have a wide range of operating intentions (Pratt, 2005);

- $\quad$ application of a single didactic model for a long time makes students bored (Joyce et al., 2004);

- in pursuance of quality of studies, teaching, and learning, students should be familiar with the variety of didactic and learning situations (Meirieu et al., 1996);

- a large variety of available didactic models ensure the adaptability to and flexibility in various didactic and learning situations (Vienneau, 2005).

The above authors' studies conclude that a lecturer may play a variety of roles in didactic activities ("coach", "instructor", "didactician", "ferry man", etc.), depending on a didactic model chosen (transmissible, behavioural, constructivist, socio-constructivist, etc.) or a constructing position of professional behaviour. Therefore, one can assume that lecturers, when taking 
various roles, represent different didactic models, different behaviours, and respective values (Jorrin, 2003):

- a lecturer, taking a "coach's" role, represents the behaviour or performance mastering position. A coach's role involves a movement toward the performance improvement, toward the search for certain tools and their application. This role, thus, allows motivating a student, observing and encouraging his/her efforts. A positive lecturerto-student relationship assures successful and productive learning. Taking this role is associated with the diagnostic educational evaluation, upon refusal of traditional control. Preset, current, and required performance excellence is assessed. A learner's individual learning style and tempo are taken into account. The entire process of knowledge and skill acquisition is foreseen;

- a lecturer, taking an "instructor's" role, represents the behaviour or performance effectiveness position, which is prevailed by success, self-improvement, performance, superiority, individualism, motivation, self-sufficiency values. Effectiveness position is directly related to learning-based targets, objectives of activities. An instructor's role involves traditional knowledge transfer to students. The transmission model cannot do without knowledge control procedures. Assessment of knowledge and skills, classification of the activities carried out, production, achievements are the most common elements of the "instructor" role performer. The main method of activities is a classic lecture; evaluation has a normative and cumulative nature;

- a "didactician's" role represents the behaviour or performance constructing position and values such as accuracy, mediation, counselling. A didactician's role involves the provision and creation of prerequisites for acquisition of knowledge and skills. A didactician is planning means which could be helpful for students in developing independence of thinking, reasoning and actions. Problem-solving is a basis of the didactician's performance, whereby much attention is paid to students' social representations, creation of complex learning situations, evaluation of the educator, discipline, formation and mastering of skills needed for professional activities. Therefore, it can be said that a didactician is an expert in his/her field, a professional teacher, a practician. Construction and proposal of didactic situations to students reveals a pragmatism-based teaching practice. Pragmatic vision of such lecturer allows constructing complex, flexible, and 
easily modelled didactic situations with reference to constructivist and socio-constructivist learning;

- a "ferry man's" ("escort's") role represents the behaviour or performance understanding, comprehension position, which values are acceptance and recognition of "others". Therefore, the position of understanding, comprehension is consistent with basic humanistic ideas, seeks the respect to oneself and others. The learning process involves even the aspects which students often do not speak about: a failure, fear of learning, lack or absence of motivation, etc. Therefore, a lecturer, while taking a ferry man's role, is mobilizing all his/her available skills of attentive listening, empathy, acceptance of another person, etc. A ferry man observes a student's learning problems, difficulties, thus, attempts renewing a constructive dialogue between the student's inner world and the educational establishment's requirements (Jorrin, 2003, p. 70). Such attention to another person is inseparable from the behaviour constructing position and approach selected by the lecturer. To renew the broken contact between a student's inner world and the educational establishment, a ferry man refers to the student's beliefs, knowledge, values, as well as the educational establishment's values, symbols, and demands. Therefore, development of a student's independent, critical thinking, selfconfidence, socio-cognitive conflict solving, analysis of divergence behaviour concept, professional ethics, responsibility, etc. are of particular importance. A lecturer, in carrying out this role, should understand neuro-linguistic programming (NLP), transactional analysis (TA) techniques, social psychology or, even, psychoanalysis, as required for dealing with unpredicted, unforeseen incidents and problems (Jorrin, 2003, p. 72).

All the four above behavioural positions may be conflicting to each other, cause tensions, contradictions subject to their correlation when choosing them as the key positions in the professional behaviour development process. Therefore, the development, construction of professional behaviour, selection and performance of a role are determined by our (lecturers') own discretion to choose one or the other position and representative values. The selected role and behaviour also depend on a dominating approach to professional behaviour construction: tactical, strategic, or ethical.

In case of dominating an ethical approach to professional behaviour construction, a lecturer attaches high priority to values, aspirations, visions of the world, caring for others and oneself, to an inner dialogue. If a tactical approach to professional behaviour construction is dominant, a lecturer attaches great importance to practice, operating "strings", advice, professional secrets, an 
intuitiveness, a fragmented, peripheral, often artisanal or, even, "poaching" performance, which is often based neither on scientific knowledge nor on professional standards. In case of a dominating strategic approach to professional behaviour construction, a lecturer focuses on research publications, performance objectives, index of competitiveness, competence and job descriptions, rational activity, structured actions, etc.

Lecturers with little experience and low self-confidence incur concerns about their professionalism, which do not allow them judging their performance objectively. As a result, they construct their professional behaviour on the basis of the ethical approach to behaviour construction. On the other hand, highly experienced lecturers base their professional behaviour on the strategic approach since being able to perfectly adapt their behaviour to standard expectations and requirements of an educational establishment, to explain their actions to management of the establishment, peers, social partners, and students. The ethical approach is inherent to lecturers who are pursuing professional behaviour, operational innovation. This is a case of intersection of social representations and reality involving continuous self-evaluation, reflection, assessment of other academic staff's performance.

It is assumed that there is no good or bad approach to the construction of professional behaviour since a lecturer's professional identity, professional behaviour are constructed on the basis of all the three approaches and any possible combinations thereof (Jorrin, 2003, p. 67). Nonetheless, the most important thing is being aware of the different approaches to behaviour construction, the ability to choose and apply them properly. Therefore, we should assume that the consideration of lecturers' professional behaviour, its analysis may become a determinant, an element of their professionalisation, it may point out strategies or means of academic staff's professional development.

\section{Conclusions}

1. Didactic preparation is not mandatory for academic staff in Lithuania. It is therefore assumed that some lecturers are not even aware of what higher school didactics-based pedagogical activities mean. That implies problematic issues of lecturers' professionalism notion, of their professionalization process.

2. The essence of didactic practice conceptualisation lies in certain academic staff's performance patterns, models, roles that may be reference points to enable lecturers to understand, explain, focus, and construct their didactic practices. Thus, the conceptualisation of didactic practices may be regarded as one of the lecturers' professionalisation means and factors that stimulate professional development. There are several types of didactic practice 
concepts: developed or complex, involving many elements of didactic and learning activities, and simple, often restricted to one specific element. So, lecturers' didactic practices are assumed to be focused on knowledge and information transfer. Simple concepts are supposed to hinder a lecturer in understanding and applying a model of didactic practices. Conversely, developed, complex concepts of didactic practices have a positive influence on the choice and application of a student- or learning-oriented didactic approach or strategy.

3. Scientific studies show that lecturers' professional behaviour largely depends on the conceptualisation of their didactic practices. In other words, there is a direct interrelation of conceptualisation of didactic practices and professional behaviour, performance models, and roles. Whoever comprehends and is able to explain their didactic practice, will be able to improve it based on on a clear vision of didactic practice. It can be said that a university is not only a place for formation and dissemination of new scientific knowledge - it is a place for learning/training, acquisition of skills needed for professional activities, too. A lecturer may play important and different roles in the learning/studies and skill acquisition process. Therefore, a variety of lecturers' roles is closely related to a diversity of didactic models. When applying various didactic models during classes, a lecturer can perform multiple respective roles and models. This raises students' interest in classes, in the lecturer, stimulates acquisition of new knowledge and skills.

4. Based on studies in the conceptualisation of didactic practices, we can state that the consideration of diverse conceptualisation of academic staff's didactic practices, their professional behaviour, and analysis thereof may provide necessary elements to their professionalisation, to point out appropriate strategies or means of professional development.

\section{References}

Clanet, J. (2004). Que se passe-t-il en cours? Éléments de description des pratiques enseignantes à l'Université [What is going on? Elements of description of teaching practices at the University]. In Dans E. Annoot \& M.-F. Fave-Bonnet, Pratiques pédagogiques dans l'enseignement supérieur: Enseigner, apprendre, évaluer [Teaching Practices in Higher Education: Teaching, Learning, Evaluation] (pp. 93-125). Paris, France: L'Harmattan.

Fox, D. (1983). Personal theories of teaching. Studies in higher education, 8 (2), pp. 151-63.

Dall'Alba, G. (1991). Foreshadowing conceptions of teaching. In B. Ross (dir.), Teaching for effective learning. Research and development in higher education (Vol. 13, pp. 293297). Sydney, NSW: HERDSA.

Donnay, J., \& Romainville, M. (1996). Politiques de formation pédagogique des professeurs d'université [Policies for pedagogue training of university professors]. In J. Donnay \& 
M. Romainville (Dir.), Enseigner à l'université, un métier qui s'apprend? [Teaching at the University. A craft that can be learned?] Brussels, Belgium: De Boeck.

Dunkin, M.-J. (1990). The induction of academic staff to a university: Processes and products. Higher Education, 20 (1), pp. 47-66.

Jasper, K. (1998). Filosofijos ivadas [Introduction to philosophy]. Vilnius, Lithuania: Pradai. Jatkauskienè, B., \& Andriekienè, R. M. (2013). Universiteto dèstytoju veiklos daugiafunkcionalumas profesionalizacijos kontekste. Klaipedos universiteto atvejis. Monografija [Multifunctionality of university teachers' activities in the context of professionalization. Study case of Klaipeda University. Monograph]. Klaipeda, Lithuania: Klaipeda University Press. ISBN 978-9955-18-722-6.

Jatkauskienė, B., Andriekienė, R. M., \& Trakšelys, K. (2014). Universiteto dèstytojų didaktinè veikla: reali praktika, problemos, poreikiai [Didactic activities of university teachers: real practice, problems, needs]. Andragogika. Mokslo darbai [Andragogy. Scientific publications] 1 (5), pp. 65-84, Klaipėda, Lithuania: Klaipèda University Press. ISSN2029-6894, Retrieved from http://www.tsi.lt/galery/_tsi/doc/katedra/ andragogika_nr.4.pdf

Jorro, A. (2003). Professionnaliser le métier d'enseignement [Professionalisation in teaching profession]. Paris, France: ESF.

Joyce, B., Weil, M., \& Calhoun, E. (2004). Models of Teaching (7th ed.). Boston, MA: Allyn and Bacon.

Kane, R., Sandretto, S., \& Heath, C. (2002). Telling the half of the story: a critical review of research on the teaching beliefs and practices of university academics'. Review of educational research, 72 (2), pp. 177-228.

Kember, D. (1997). A reconceptualisation of the research into university academics' conceptions of teaching. Learning and instruction, 7 (3), pp. 255-275.

Langevin, L. (2007). Conceptions, besoins et pratiques pédagogiques de professeurs d'université: perspectives pour la formation [Concepts, needs and pedagogical practices of university professors: perspectives for training] (p. 18). Montreal, Canada: University of Quebec.

Legendre, M.-F. (2004). Cognitivisme et socioconstructivisme: des fondements théoriques à leur utilisation dans l'élaboration et la mise en oeuvre du nouveau programme de formation [Cognitivism and socio-constructivism: from theoretical foundations to the use of them in the development and implementation of a new training programme]. In P. Jonnaert \& A. M'Batika (dir.), Les réformes curriculaires: Regards croisés [Curriculum reforms: Cross-checking] (pp. 15-47). Quebec, Canada: Presses of the University of Quebec.

Legendre, R. (2005). Dictionnaire actuel de l'éducation [Current dictionary of education] (3rd ed.). Montreal, Canada: Guérin.

Loiola, F. A. (2001). Les conceptions éducatives des nouveaux professeurs d'université dans un contexte particulier de socialisation formelle à l'enseignement. Thèse de doctorat inedited [Educational conceptions of new university professors in a special context of formal socialisation in teaching. Unpublished Doctoral Thesis]. Sainte-Foy, Canada: Laval University.

Meirieu, P., Devela, M., Durand, C., \& Mariani, Y. (1996). Le transfert des connaissances en formation initiale et en formation continue [Transfer of knowledge in initial and continuing education]. Lyon, France: CRDP. 
Neyts, L., Nils, F., Parmentier, P., Noël, B., \& Verwaerde, A. (2006). Regards étudiants sur les dispositifs d'aide à la réussite à l'Université Catholique de Louvain, aux Facultés Universitaires Catholiques de Mons et aux Facultés universitaires Saint-Louis [Student Views on Success Stories at the Catholic University of Louvain, Faculties of the Catholic University of Mons and Faculties of the Saint-Louis University]. In P. Parmentier (dir.), Promotion de la réussite des nouveaux bacheliers à l'Université [Promoting the success of new bachelors in the university] (pp. 43-59). Namur, Belgium: Presses of the University of Namur.

Pratt, D. D. (1992). Conceptions of teaching. Adult education quarterly, 42 (4), pp. 203-220.

Pratt, D. D. (2005). Five Perspectives on Teaching in Adult and Higher Education. Malabar, FL: Krieger.

Ramsden, P. (2003). Learning to Teach in Higher Education. New York, NY: Routledge.

Romainville, M. (1996). Politiques de formation pédagogique des professeurs d' Université [Policies for pedagogue training of university professors]. In J. Donnay \& $\mathrm{M}$. Romainville (Dir.), Enseigner à l'université, un métier qui s'apprend? [Teaching at the University. A craft that can be learned?] (pp. 78-94). Brussels, Belgium: De Boeck.

Romainville, M. (1998). Les "nouveaux" étudiants [The "new" students]. In. M. Frenay, B Noël, Ph. Parmantier, \& M. Romainville (dir.), Ĺ étudiant - apprenant. Grlles de lecture pour l'enseignement universitaire [The student-learner. Reading grids for university education] (pp. 149-166). Paris, France: De Boeck et Larcier.

Samuelowicz, K., \& Bain, J. (1992). Conceptions of teaching held by academic teachers. Higher Education, 24, pp. 93-111.

Saussez, F. (1998). Vers un cadre conceptuel pour l'étude de déterminants des conceptions des enseignants de l'enseignement supérieur à propos de l'acte d'enseigner. Mémoire inédit de licence en sciences de l'éducation, préparatoire au doctorat [Towards a conceptual framework for the study of determinants of the conceptions of higher education teachers about the act of teaching. Unpublished dissertation in the sciences of education, preparatory to the doctorate]. Louvain-la-Neuve, Belgium: Catholic University of Louvain.

Schön, D. A. (1994). Le praticien réflexif [The reflective practitioner] (p. 53). Montreal, Canada: Editions Logiques.

Šedžiuvienè, N. (2005). Kolegijų dèstytojų pedagoginès veiklos vertinimo sistemos sudarymas (principai ir kryptys) [Developing the assessment system for college teachers' pedagogical activities (principles and areas)]. Pedagogika [Pedagogy], 76, pp. 33-38. Vilnius, Lithuania: VPU.

Trigwell, K., Prosser, M., \& Taylor, P. (1994). Qualitative differences in approaches to teaching first year university science. Higher Education, 27, pp. 75-84.

Trowler, P. R., Saunders, M., \& Bamber Veronica (dir.). (2011). Reconceptualising Evaluation In Higher Education: The Practice Turn. Maidenhead, UK: Open University Press.

Vienneau, R. (2005). Apprentissage et enseignement [Learning and teaching]. Montreal, Canada: Gaëtan Morin. 